\title{
Anticancer Potential of Aqueous Ethanol Seed Extract of Ziziphus mauritiana against Cancer Cell Lines and Ehrlich Ascites Carcinoma
}

\author{
Tulika Mishra, ${ }^{1}$ Madhu Khullar, ${ }^{2}$ and Aruna Bhatia ${ }^{1}$ \\ ${ }^{1}$ Immunology and Immunotechnology Laboratory, Department of Biotechnology, Punjabi University, Patiala, Punjab 147002 , India \\ ${ }^{2}$ Experimental Medicine \& Biotechnology, Post Graduate Institute of Medical Education \& Research, Chandigarh 160 012, India
}

Correspondence should be addressed to Aruna Bhatia, tulika_chd@yahoo.com

Received 9 May 2010; Revised 9 May 2010; Accepted 10 July 2010

Copyright (C) 2011 Tulika Mishra et al. This is an open access article distributed under the Creative Commons Attribution License, which permits unrestricted use, distribution, and reproduction in any medium, provided the original work is properly cited.

\begin{abstract}
Ziziphus mauritiana (Lamk.) is a fruit tree that has folkloric implications against many ailments and diseases. In the present study, anticancer potential of seed extract of Ziziphus mauritiana in vitro against different cell lines (HL-60, Molt-4, HeLa, and normal cell line HGF) by MTT assay as well as in vivo against Ehrich ascites carcinoma bearing Swiss albino mice was investigated. The extract was found to markedly inhibit the proliferation of HL-60 cells. Annexin and PI binding of treated HL-60 cells indicated apoptosis induction by extract in a dose-dependent manner. The cell cycle analysis revealed a prominent increase in sub Go population at concentration of $20 \mu \mathrm{g} / \mathrm{ml}$ and above. Agarose gel electrophoresis confirmed DNA fragmentation in HL-60 cells after $3 \mathrm{~h}$ incubation with extract. The extract also exhibited potent anticancer potential in vivo. Treatment of Ehrlich ascites carcinoma bearing Swiss albino mice with varied doses (100-800 mg/kg b.wt.) of plant extract significantly reduced tumor volume and viable tumor cell count and improved haemoglobin content, RBC count, mean survival time, tumor inhibition, and percentage life span. The enhanced antioxidant status in extract-treated animals was evident from decline in levels of lipid peroxidation and increased levels of glutathione, catalase, and superoxide dismutase.
\end{abstract}

\section{Introduction}

The plant-derived compounds have always been an important source of medicines for various diseases and have received considerable attention in recent years due to their diverse pharmacological properties including cytotoxic and cancer chemopreventive effects [1]. During the last few years, novel chemopreventive agents of natural origin have been targeted with fruits and vegetables being a key interest due to high content of bioactive compounds [2]. Cancer is the second leading cause of death all over the world [3]. According to World Health Organization, more than 10 million new cases of cancer are diagnosed every year, and the statistical trends indicate that this number would double by 2020 [4]. Cancer is the uncontrolled growth and spread of abnormal cells, associated with dysregulation of apoptosis, a programmed cell death. Most of the current anticancer drugs are derived from plant sources, which act through different pathways converging ultimately into activation of apoptosis in cancer cells leading to cell cytotoxicity.
Ziziphus mauritiana commonly known as Indian jujube is a fruit tree belonging to family Rhamnaceae. Traditionally, the fruit has been used as anodyne, sedative, tonic anticancer, potent wound healer, applied on cuts and ulcers and has also been used against asthma $[5,6]$. The extracts from fruits [7], leaves [8,9], and seeds [10] of Ziziphus mauritiana have been reported to exhibit antioxidant activity, whereas bark $[11,12]$ and pulp [13] are reported to possess cytotoxicity against different cancer cell lines. Keeping above in view, the present study was aimed at investigating the effect of aqueous-ethanolic seed extract of Ziziphus mauritiana against different cancer cell lines in vitro and against Ehrlich ascites carcinoma in vivo.

\section{Materials and Methods}

2.1. Chemicals and Reagents. 3-(4,5-dimethylthiazole-2- yl)2,5-diphenyltetrazolium bromide (MTT), RPMI-1640, Lglutamine, penicillin, streptomycin, HEPES, 2-mercaptoethanol, propidium iodine (PI), DNase free RNase, proteinase 
K, 2-Deoxy-D-ribose, ascorbic acid, and 1,1-diphenyl-2picrylhydrazyl (DPPH) were purchased from Sigma chemical Co, St. Louis, USA. Fetal Bovine serum (FBS) was purchased from GIBCO Invitrogen Corporation, USA. Annexin VFITC apoptosis detection kit and Cycle test were purchased from BD Bioscience, USA. Electrophoresis apparatus and reagents were procured from Biorad, USA. Trichloro acetic acid (TCA), Thiobarbituric acid (TBA), and pyragallol were purchased from Merck, USA. All other chemicals used were of analytical grade, available locally.

2.2. Plant Source, Extract Preparation, and Standardization (ZMS). Fruits of Ziziphus mauritiana (Lamk.), variety Umran were collected from Botanical Gardens of Punjabi University, Patiala, Punjab, India and authenticated by Professor R.C. Gupta, Botany Department, Punjabi University, Patiala, Punjab, India. Plant sample has been kept in Voucher specimen DOB (305) PUP at Punjabi University, Patiala. Aqueous-ethanolic seed extract of Ziziphus mauritiana (ZMS) was prepared and standardized as described earlier [14].

\subsection{Anticancer Activity of ZMS In Vitro}

2.3.1. Cell Lines, Growth Conditions, and Treatment. Human promyelocytic leukemia cells (HL-60), acute lymphoblastic leukemia cells (Molt-4), human cervical cancer cells (HeLa) cells, and normal human gingival fibroblast cells (HGF) were obtained from National Cancer Institute (NCI), Bethesda, USA.

The cells were grown in RPMI-1640 medium, supplemented with $10 \%$ heat-inactivated fetal bovine serum (FBS), penicillin (100 units $/ \mathrm{mL})$, streptomycin $(100 \mu \mathrm{g} / \mathrm{mL})$, HEPES $15 \mathrm{mM}$, L-glutamine $(0.3 \mathrm{mg} / \mathrm{mL})$, pyruvic acid $(0.11 \mathrm{mg} / \mathrm{mL}), 2$-mercaptoethanol $(50 \mu \mathrm{M})$, and $\mathrm{NaHCO}_{3}$ $(0.37 \%)$ and incubated at $37^{\circ} \mathrm{C}$ in an atmosphere of $95 \%$ air and $5 \% \mathrm{CO}_{2}$, with $98 \%$ humidity. ZMS was dissolved in $30 \%$ dimethyl sulfoxide (DMSO) and delivered to cell culture in complete medium while the controls received only DMSO $(<0.2 \%, \mathrm{v} / \mathrm{v})$.

2.3.2. Cell Proliferation Assay. Cell proliferation was assessed according to the method of Shashi et al. [15]. Briefly, $200 \mu \mathrm{L}$ of medium containing $2.5 \times 10^{4}$ cells obtained from different cell lines (HL-60, Molt-4, HeLa cells, and HGF) were seeded in each well of 96-well microtiter plates. Cells were incubated with different concentrations of ZMS for $48 \mathrm{hrs}$ at $37^{\circ} \mathrm{C}, 5 \% \mathrm{CO}_{2}$ with $98 \%$ humidity. The medium was replaced with fresh medium containing $100 \mu \mathrm{g} / \mathrm{mL}$ of 3-(4,5-dimethylthiazole-2-yl)-2,5-diphenyltetrazolium bromide (MTT) for 4 hrs. The supernatant was aspirated and MTT-formazan crystals were dissolved in $100 \mu \mathrm{L}$ DMSO. Absorbance was measured at $570 \mathrm{~nm}$. Cell growth was calculated by comparing the absorbance of treated and untreated cells. Cell line showing maximum sensitivity was subjected to further study.

2.3.3. Flow Cytometric Analysis of Apoptosis and Necrosis. Flow cytometric analysis of apoptosis and necrosis was done by method of Del Bino et al. [16]. HL-60 cells treated with ZMS were washed twice with phosphate buffered saline (PBS) and then resuspended in $100 \mu \mathrm{L}$ of binding buffer provided with apoptosis detection kit (BD Pharmingin). Cells were stained with annexin-V FITC antibody and PI as per instructions provided by the manufacturer and scanned for fluorescence intensity in FL-1 (FITC) and FL-2 (PI) channels. The fractions of cell population in different quadrants were analyzed using quadrant statistics. Cells in the lower right quadrant represented apoptosis and in the upper right represented postapoptotic necrosis.

2.3.4. DNA Content and Cell Cycle Phase Distribution. Cell cycle phase distribution was done by the method of Del Bino et al. [16]. Cells were treated with different concentrations of ZMS for 24 hrs and collected at $160 \times \mathrm{g}$ for 5 minutes in $5 \mathrm{~mL}$ polystyrene tubes. Cells were washed once with PBS and fixed in $70 \%$ ethanol overnight at $4^{\circ} \mathrm{C}$. Cells were again washed with PBS, resuspended in $250 \mu \mathrm{L}$ PBS, incubated with RNase at $37^{\circ} \mathrm{C}$, and stained with propidium iodine using procedures and reagents as described in the instruction manual. The preparations were analyzed for DNA content using BD-LSR flow cytometer. Data were collected in list mode on 10,000 events for FL2-A versus FL2-W.

2.3.5. DNA Fragmentation. DNA fragmentation was assessed by electrophoresis of extracted genomic DNA from HL60 cells as described by Muller et al. [17] with slight modifications. Briefly, $2 \times 10^{6}$ cells were incubated with different concentrations of ZMS for 24 hours and washed with PBS containing $10 \mathrm{mM}$ EDTA. The pellet was lysed in $250 \mu \mathrm{L}$ of lysis buffer ( $100 \mathrm{mM} \mathrm{NaCl}, 5 \mathrm{mM}$ EDTA, $10 \mathrm{mM}$ Tris-HCl, pH 8.0, 5\% Triton X-100, 0.25\% SDS), containing $400 \mu \mathrm{g} / \mathrm{mL}$ DNase-free RNase and incubated at $37^{\circ} \mathrm{C}$ for 90 minutes followed by 1 hour incubation with proteinase$\mathrm{K}(200 \mu \mathrm{g} / \mathrm{mL})$ at $50^{\circ} \mathrm{C}$. DNA was extracted with $200 \mu \mathrm{L}$ of phenol:chloroform: isoamyl alcohol $(25: 24: 1)$ for 1 minute and centrifuged at $13000 \times \mathrm{g}$ for 3 minutes. The aqueous phase was further extracted with chloroform and centrifuged. DNA was precipitated from aqueous phase with 3 volumes of chilled alcohol containing $0.3 \mathrm{M}$ sodium acetate at $4^{\circ} \mathrm{C}$ overnight. The precipitate was centrifuged at $13000 \times$ g for 10 minutes. DNA pellet was washed with $80 \%$ alcohol, dried, dissolved in $50 \mu \mathrm{L}$ TE buffer and electrophoresed in $1.8 \%$ agarose gel at $50 \mathrm{~V}$, stained with ethidium bromide, and visualized in Bio-rad Gel Documentation System.

For the time-dependent study, $2 \times 10^{6}$ cells were incubated with specified concentrations of ZMS for 24 hours and studied at different time intervals.

\subsection{Anticancer Activity of ZMS In Vivo}

2.4.1. Animals. Male Swiss albino mice (18-22 g) maintained on standard laboratory diet (Kisan Feeds Ltd., Mumbai, India), having free access to tap water, were employed in the present study. The animals were housed in the departmental animal house and exposed to 12 hours cycle of light and dark. Experimental protocol was approved by Institutional Animal Ethics Committee and care of the animals was carried out as 


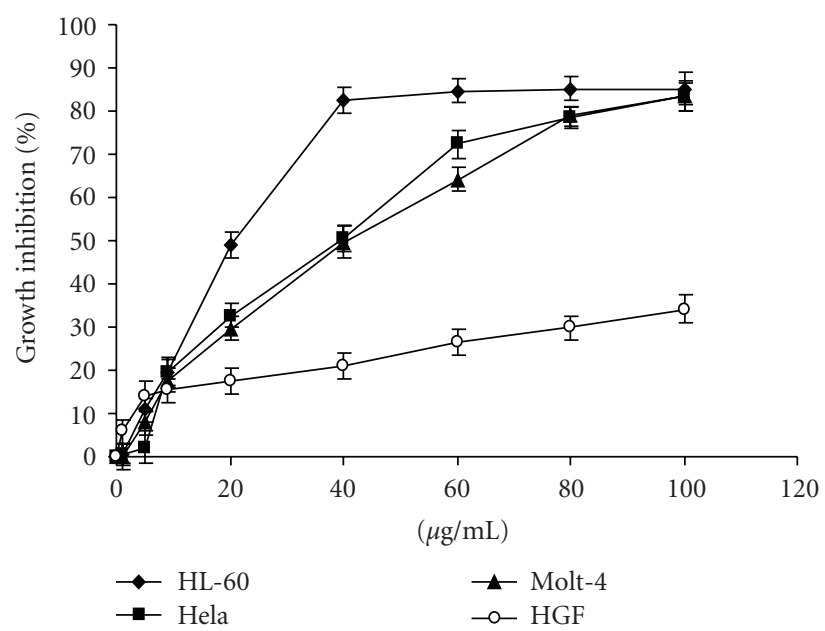

FIGURE 1: Proliferation inhibition in different human cell lines upon ZMS treatment. ZMS at indicated concentrations were evaluated for its in vitro cytotoxicity against different cancer cell lines (HL-60, HeLa, and Molt-4) and normal cell line (HGF) employing MTT reduction assay. The results are expressed as percent of cell growth inhibition determined relative to untreated control cells. Data are mean value \pm S.E.M. $(n=8)$ and representative of one of the three similar experiments.

per the guidelines of Committee for the Purpose of Control and Supervision of Experiments on Animals (CPCSEAs), Ministry of Environment and Forests, Government of India (Reg. no. 107/1999/CPCSEA).

2.4.2. Acute Toxicity. The acute toxicity of Ziziphus mauritiana seed extract was assessed as described earlier [18].

2.4.3. Experimental Design. Ehrlich Ascites Carcinoma (EAC) cells maintained in the peritoneal cavity of Swiss albino mice (male) were collected from an animal having 8-10 days old ascitic tumor by aspirating the ascitic fluid in sterile isotonic saline. The viable EAC cells were counted (trypan blue indicator) under microscope. Male Swiss albino mice weighing $18-22 \mathrm{~g}$ were injected with $1 \times 10^{7}$ EAC cells intraperitoneally on day 0 . A day of incubation was allowed for multiplication of the cells. On day 1, the animals were randomized and divided into seven groups $(n=10)$, namely, Group I, vehicle (Distilled water, i.p); Group II, Control 5-fluorouracil (20 mg/kgb.wt.); Group III, extract (100 mg/kg b.wt.); Group IV, extract $(200 \mathrm{mg} / \mathrm{kg}$ b.wt.); Group V, extract (400 mg/kg b.wt.); Group VI, extract ( $800 \mathrm{mg} / \mathrm{kg}$ b.wt.); Group VII, Control $\left(1 \times 10^{7}\right.$ EAC cells). Test groups were treated with plant extract prepared in distilled water intraperitoneally at the interval of 24 hours from day 1 to day 9. Positive control group was treated with 5-fluorouracil (commercial anticancer drug) from day 1 to day 9, parallel control group was treated with distilled water only. The animals were sacrificed on day 13 by cervical dislocation and tumor volume, tumor cell count, hematological parameters and antioxidant status were assessed. The second set of animals was continued with the similar design so as to observe their life span.

2.4.4. Tumor Growth Response. The antitumor effect of ZMS was assessed by change in body weight, ascites tumor volume, viable tumor cell count, percentage tumor inhibition, mean survival time and percentage increased life span $[19,20]$.

The tumor growth inhibition was calculated as follows:

$\%$ tumor inhibition

$=1-$ Av. No. of cells in test group

/Av. No. of cells in control group $\times 100$.

The effect of ZMS on tumor growth was monitored by recording the mortality for the period of 40 days and percentage increase in life span was calculated as follows:

$$
\begin{aligned}
& \% \text { ILS } \\
& =[(\text { Mean survival time of treated group } \\
& \quad \text { Mean survival time of control group } \times 100)-1],
\end{aligned}
$$

Mean Survival

$=($ Day of 1 st death + Day of last death $) / 2$.

Body weight of the animals was recorded both in treated and control groups at the beginning of the experiment and subsequently on every 5 th day.

2.4.5. Hematological Studies. Blood was collected from retroorbital plexus of animals and used for the estimation of hemoglobin $(\mathrm{Hb})$ content, red blood cell count (RBC), and white blood cell count (WBC) [21] and animals were sacrificed by cervical dislocation.

2.4.6. Biochemical Assays. The liver of animals was excised, rinsed in ice-cold normal saline followed by $0.15 \mathrm{M}$ Tris$\mathrm{HCl}$ ( $\mathrm{pH}$ 7.4), blotted dry, and weighed. A 10\% (w/v) homogenates was prepared in $0.15 \mathrm{M}$ Tris- $\mathrm{HCl}$ buffer and 


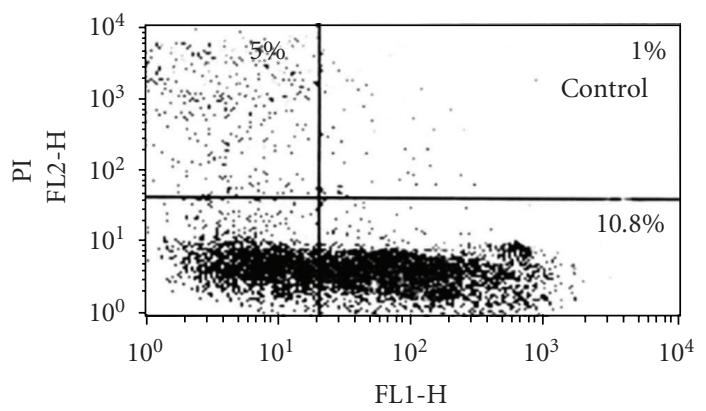

Annexin V-FITC

(a)
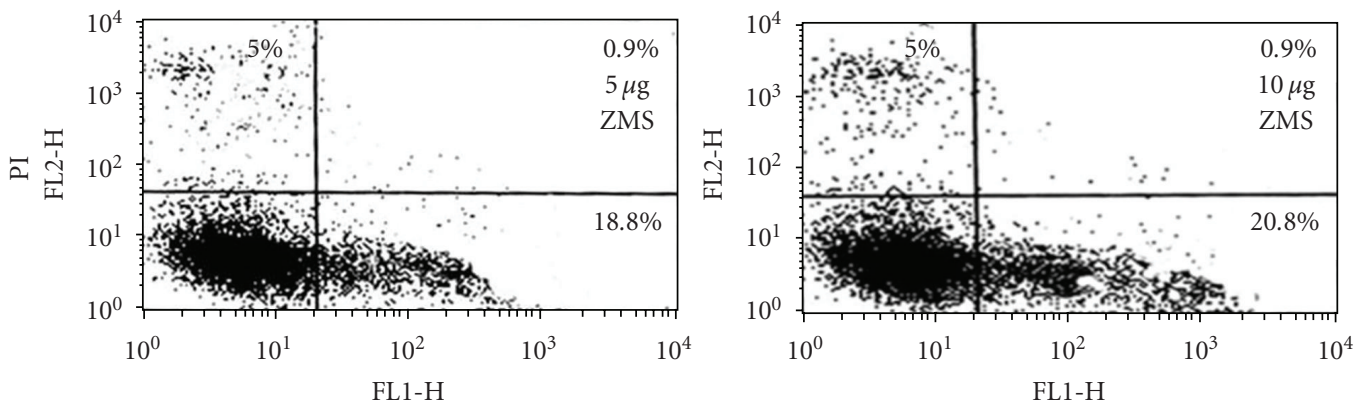

Annexin V-FITC

(b)
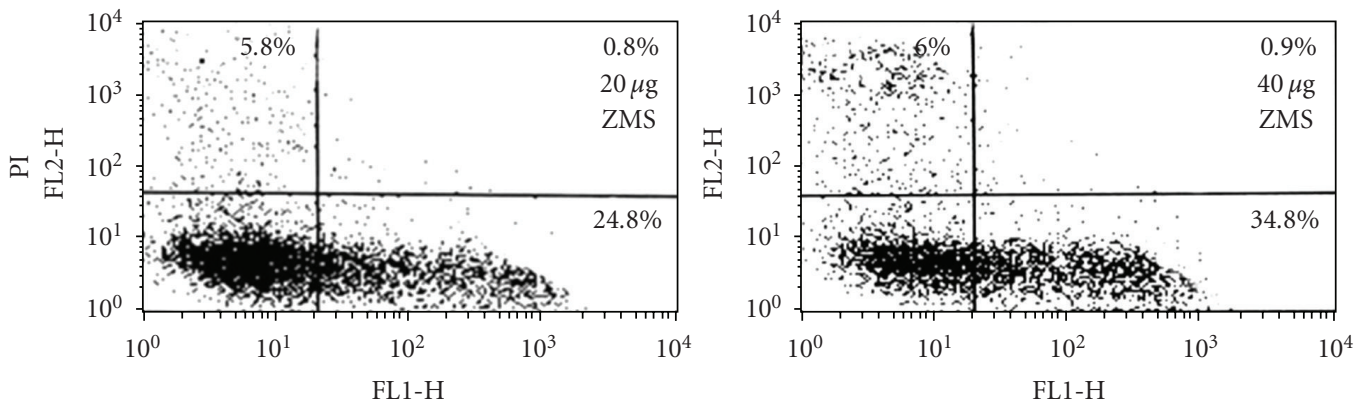

Annexin V-FITC

(c)
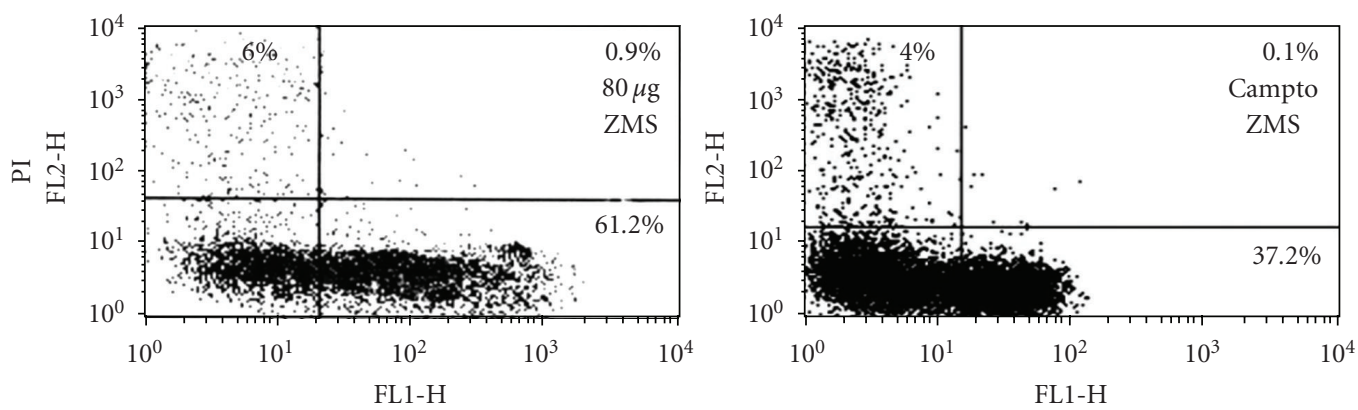

Annexin V-FITC

(d)

Figure 2: Flow cytometric analysis of ZMS-induced apoptosis and necrosis in HL-60 cells using annexinV-FITC and PI double staining. HL60 cells $(1 \times 106 / \mathrm{mL})$ were incubated with indicated concentrations of ZMS for 12 hours and stained with Annexin V-FITC/PI. Quadrant analysis of fluorescence intensity of ungated cells in FL-1 versus FL-2 channels was from 10000 events. Cells in the lower right quadrant represented apoptosis while in the upper right quadrant indicated postapoptotic necrosis and representative of one of the three similar experiments. 


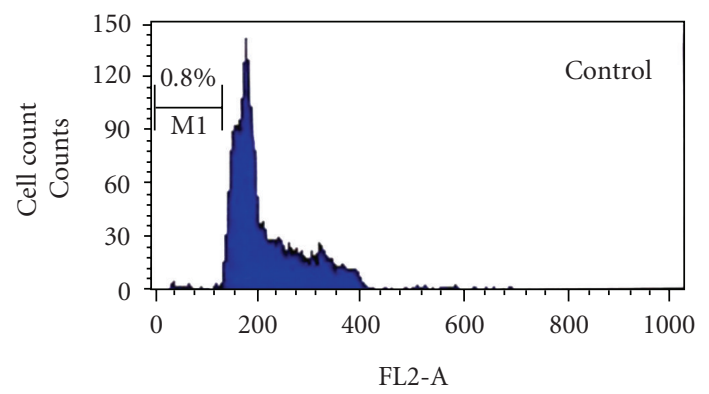

DNA Content

(a)
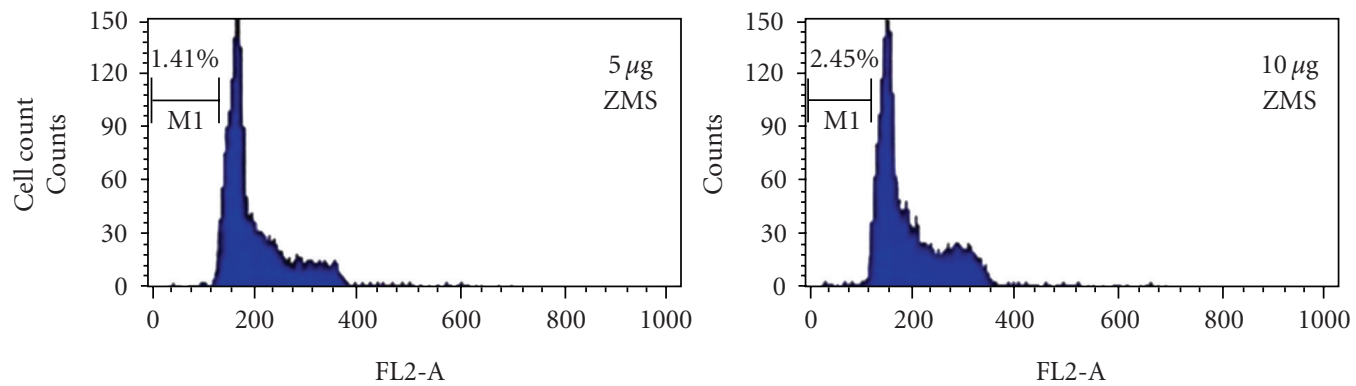

DNA Content

(b)
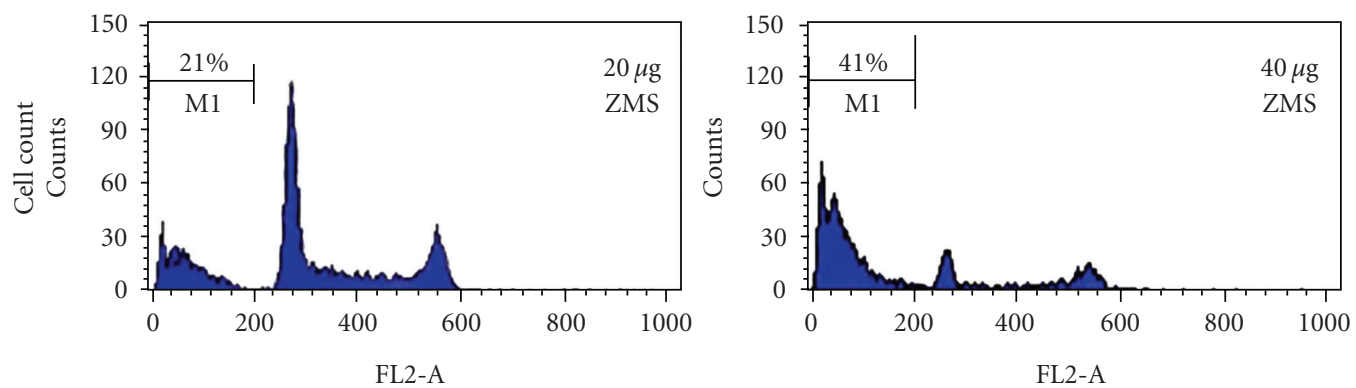

DNA Content

(c)
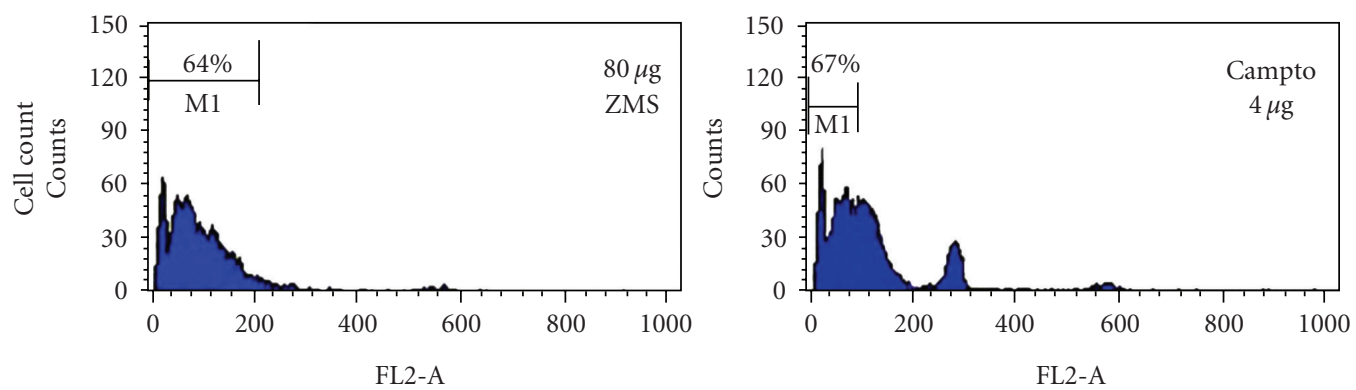

DNA Content

(d)

FIgURE 3: Cell cycle analysis in HL-60 cells after ZMS treatment. HL-60 cells $(1 \times 106 / \mathrm{mL})$ were treated with different concentration of ZMS for 24 hours. Cells were stained with PI to determine DNA fluorescence by flow cytometer. Sub-GO population indicative of DNA damage was analyzed from the hypodiploid sub-Go fraction $(<2 n$ DNA) of DNA cell cycle analysis. The cells for hypodiploid (sub GO/G1, $<2 n$ DNA) population were analyzed from FL2-A versus cell counts shown in $\%$ and representative of one of the three similar experiments. 


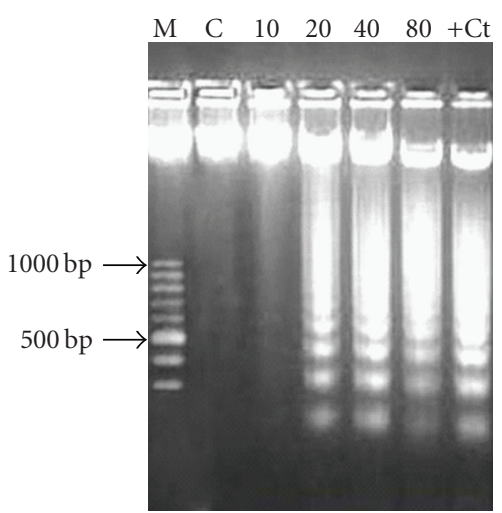

(a)

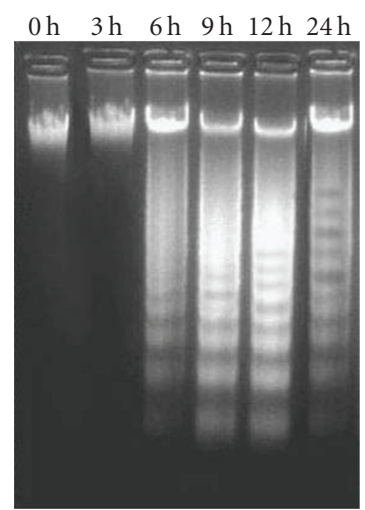

(b)

Figure 4: Dose-dependent and time-dependent induction of DNA fragmentation in HL-60 cells after ZMS treatment. (a) $2 \times 106$ HL-60 cells treated with different concentrations of ZMS extract for 24 hours. DNA was electrophoresed on $1.8 \%$ agarose gel and stained with ethidium bromide. M-Marker; C-Untreated HL-60 cells; $10-10 \mu \mathrm{g} / \mathrm{mL}$ of ZMS treated HL-60 cells; 20-20 $\mu \mathrm{g} / \mathrm{mL}$ of ZMS treated HL-60 cells; $40-40 \mu \mathrm{g} / \mathrm{mL}$ of ZMS treated HL-60 cells; $80-80 \mu \mathrm{g} / \mathrm{mL}$ of ZMS treated HL-60 cells; +Ct - Camptothecin treated HL-60 cells. (b) $2 \times 106$ HL-60 cells were treated with $20 \mu \mathrm{g} / \mathrm{mL}$ of ZMS extract and were incubated for 3 hours, 6 hours, 9 hours, 12 hours, and 24 hours. DNA was electrophoresed at respective time interval on $1.8 \%$ Agarose gel and stained with ethidium bromide.

was used for the estimation of lipid peroxidation (LPO) [22] and glutathione content (GSH) [23]. Rest of the homogenate was centrifuged at $2500 \times \mathrm{g}$ for 15 minutes at $4^{\circ} \mathrm{C}$ and superoxide dismutase (SOD) [24], catalase (CAT) [25], and total protein [26] was estimated in the supernatant.

2.4.7. Statistical Analysis. All the results of in vivo experiment were expressed as Mean \pm S.E.M. Data of tests were statistically analyzed using one-way ANOVA followed by Tukey's multiple range test, applied for post-hoc analysis. The data were considered to be statistically significant if the probability had a value of 0.05 or less.

\section{Results}

3.1. Inhibition of Cell Proliferation in Various Cell Lines by ZMS. In order to determine the anticancer potency of extract in vitro, ZMS was tested for cell growth inhibition in different cancer cell lines at various concentrations for 48 hours. The extract did not show any significant inhibitory effect against normal cell line HGF (Normal human gingival fibroblast cell line). Inhibitory effect against HL-60, Hela, and Molt- 4 was observed with IC50 value at $20 \mu \mathrm{g} / \mathrm{mL}$, $40 \mu \mathrm{g} / \mathrm{mL}$, and $40 \mu \mathrm{g} / \mathrm{mL}$, respectively. Of the tested cell lines, maximum growth inhibition was observed in HL-60 cells as shown in Figure 1, and thus HL-60 was selected for further study.

3.2. Flow Cytometric Analysis of Apoptosis/Necrosis Induced by ZMS in HL-60 Cells. In order to determine whether ZMSinduced cytotoxicity is due to apoptosis or necrosis, HL-60 cells were incubated with different concentrations of ZMS for 12 hours, and the percentage of cells undergoing apoptosis or necrosis was determined by staining with annexin V-FITC and PI (Figure 2). Cells in the lower right quadrant indicated apoptosis while in the upper right quadrant represented postapoptotic necrotic population. ZMS at $5 \mu \mathrm{g} / \mathrm{mL}$ and $80 \mu \mathrm{g} / \mathrm{mL}$ induced about $18.8 \%$ and $61.2 \%$ apoptosis. The increase in annexin V-FITC/PI positive cell population suggests that ZMS is a potent inducer of apoptosis and triggers events leading to apoptotic cell death.

3.3. Cell Cycle Analysis by ZMS Treatment. For the confirmation of apoptotic cell death induced by ZMS in HL-60 cells, the cells were treated with ZMS for 24 hours. The cells exhibited concentration-dependent increase in hypodiploid sub-Go/G1 DNA fraction (<2nDNA) (Figure 3$)$. The subGo/G1 fraction was $<1 \%$ in control cells (untreated HL-60 cells) which increased with increasing concentration of ZMS and reached to $64 \%$ at concentration of $80 \mu \mathrm{g} / \mathrm{mL}$.

3.4. DNA Fragmentation. DNA fragmentation, a characteristic feature of apoptosis, was assessed by ladder formation on agrose gel electrophoresis. HL-60 cells treated with extract showed apoptosis in a concentration-dependent manner as evidenced by the formation of internucleosomal DNA fragments (Figure 4(a)). Apoptosis induction in cells started at $20 \mu \mathrm{g} / \mathrm{mL}$ and this concentration was further selected for time-dependent study. The extract was found to induce apoptosis in cells after 3 hours of incubation as shown in Figure 4(b).

3.5. Survival Time and Tumor Growth Response. Antitumor activity of ZMS against EAC tumor-bearing mice is shown in Table 1 . The tumor volume and viable cell count significantly increased in EAC control animals. Administration of ZMS $(100,200,400$, and $800 \mathrm{mg} / \mathrm{kg}$ b.wt.) to tumor-bearing mice significantly $(P<.001)$ decreased tumor volume and viable cell count and enhanced the mean survival time in a dosedependent manner. Tumor growth inhibition upto $75.42 \pm$ $0.96 \%$ was observed at $800 \mathrm{mg} / \mathrm{kg}$ b.wt. with $70 \%$ increase in life span of test animals. 


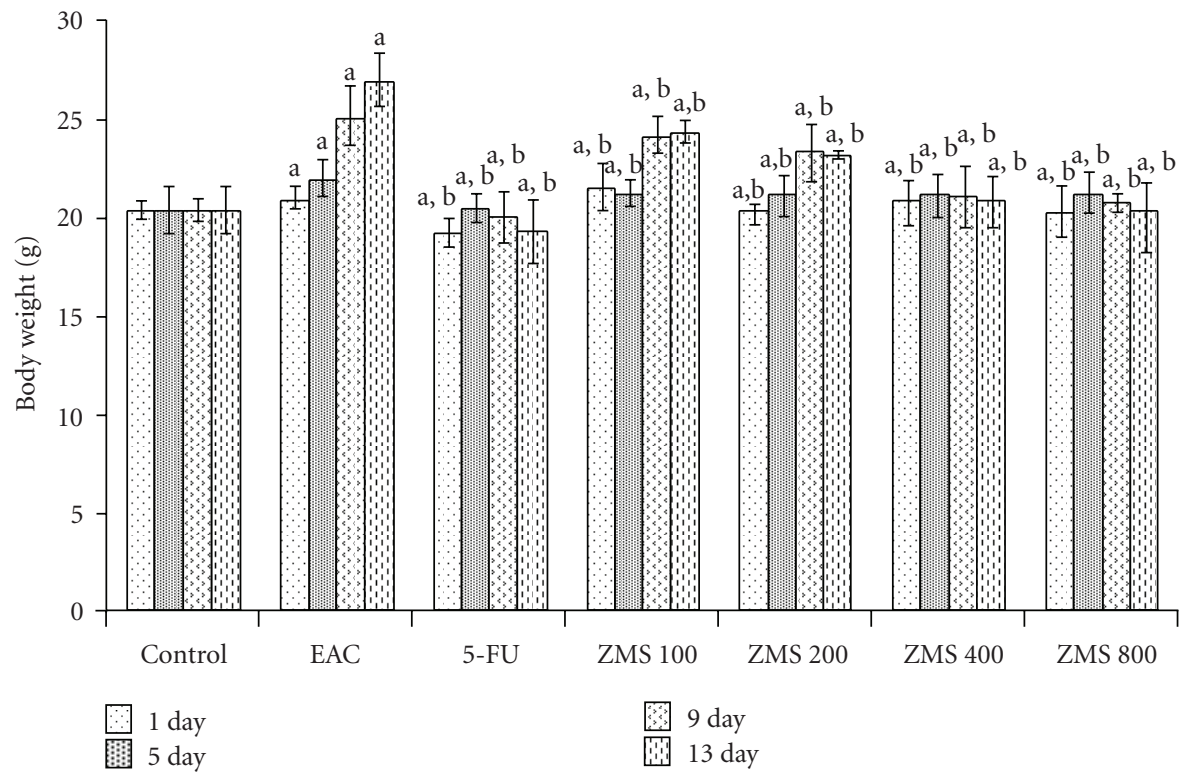

Figure 5: Change in body weight in EAC bearing mice after ZMS treatment. The results are presented as Mean \pm S.E.M. $(n=10)$. (a) $P<.001$ in comparison to untreated control; (b) $P<.05$ in comparison to EAC control group.

TABLE 1: Effect of ZMS treatment on EAC-bearing mice.

\begin{tabular}{|c|c|c|c|c|c|c|c|}
\hline \multirow{3}{*}{ Parameters } & \multicolumn{7}{|c|}{ Treatment of different groups } \\
\hline & Control & EAC & $\mathrm{EAC}+5 \mathrm{FU}$ & $\mathrm{EAC}+\mathrm{ZMS}$ & $\mathrm{EAC}+\mathrm{ZMS}$ & $\mathrm{EAC}+\mathrm{ZMS}$ & $\mathrm{EAC}+\mathrm{ZMS}$ \\
\hline & \multicolumn{2}{|c|}{ Dose (mg/kg b.wt.) } & 20 & 100 & 200 & 400 & 800 \\
\hline Hb content $(\mathrm{mg} / \mathrm{dl})$ & $13 \pm 0.5$ & $9.5 \pm 0.73^{\mathrm{a}}$ & $13.1 \pm 0.4^{\mathrm{b}}$ & $11.24 \pm 0.67^{\mathrm{b}}$ & $11.59 \pm 0.6^{\mathrm{b}}$ & $12.4 \pm 0.81^{\mathrm{b}}$ & $12.2 \pm 0.45^{\mathrm{b}}$ \\
\hline $\mathrm{WBC}\left(\right.$ cells $\left./ \mathrm{mL} \times 10^{6}\right)$ & $7.17 \pm 0.11$ & $15.6 \pm 0.64^{\mathrm{a}}$ & $7.73 \pm 0.68^{\mathrm{a}}$ & $12.1 \pm 0.75^{\mathrm{b}}$ & $9.4 \pm 0.83^{\mathrm{b}}$ & $9.2 \pm 1.26^{\mathrm{b}}$ & $8.5 \pm 0.40^{\mathrm{b}}$ \\
\hline $\mathrm{RBC}\left(\right.$ cells $\left./ \mathrm{mL} \times 10^{6}\right)$ & $5.33 \pm 0.45$ & $3.5 \pm 0.41^{\mathrm{a}}$ & $5.2 \pm 0.11^{\mathrm{b}}$ & $4.2 \pm 0.55^{\mathrm{b}}$ & $4.3 \pm 0.35^{\mathrm{b}}$ & $4.9 \pm 0.15^{\mathrm{b}}$ & $5.0 \pm 0.12^{\mathrm{b}}$ \\
\hline Tumor Volume (mL) & - & $8.3 \pm 0.79$ & $0.7 \pm 0.20^{\mathrm{b}}$ & $7.6 \pm 0.94^{\mathrm{b}}$ & $5.4 \pm 0.96^{\mathrm{b}}$ & $4.5 \pm 1.04^{\mathrm{b}}$ & $2.1 \pm 0.51^{\mathrm{b}}$ \\
\hline Viable tumor Cell Count $\left(\times 10^{7}\right)$ & - & $283.02 \pm 1.63$ & $11.17 \pm 0.96^{\mathrm{b}}$ & $186.12 \pm 1.57^{\mathrm{b}}$ & $146.27 \pm 1.43^{\mathrm{b}}$ & $109.57 \pm 1.08^{\mathrm{b}}$ & $69.59 \pm 1.62^{b}$ \\
\hline Mean Survival time (Days) & - & $20 \pm 1.41$ & $39 \pm 0.81^{\mathrm{b}}$ & $23 \pm 1.53^{\mathrm{b}}$ & $26 \pm 1.73^{\mathrm{b}}$ & $30 \pm 0.81^{\mathrm{b}}$ & $34 \pm 1.63$ \\
\hline Tumor inhibition (\%) & - & & $96.11 \pm 0.73$ & $25.67 \pm 1.09$ & $39.78 \pm 2.55$ & $57.54 \pm 1.03$ & $75.42 \pm 0.96$ \\
\hline Increase in life span (\%) & - & & 95 & 15 & 30 & 50 & 70 \\
\hline
\end{tabular}

The results are presented as Mean \pm S.E.M. $(n=10) .{ }^{\mathrm{a}} P<.001$ in comparison to normal group; ${ }^{\mathrm{b}} P<.05$ in comparison to EAC control group.

EAC-bearing mice showed rise in body weight, while the extract treatment inhibited the rise in body weight in the pattern similar to the standard drug (Figure 5).

3.6. Hematological Parameters. Hematological parameters of tumor bearing animals on day 13 were found to be significantly altered as compared to normal group (Table 1). Hemoglobin content and RBC count in EAC control group decreased while WBC count increased as compared to normal group. Treatment with ZMS at various doses increased hemoglobin content and RBC count and reduced the WBC count towards normalcy.

3.7. Lipid Peroxidation and Glutathione. Increase in malondialdehyde (MDA) levels is a measure of lipid peroxidation. Figure 6 depicts the level of lipid peroxidation in terms of MDA in liver tissue of experimental animals. It was observed that MDA levels increased by $60.6 \%$ in EAC control group as compared to normal control group $(P<.001)$. After administration of ZMS at different doses (100, 200, 400 , and $800 \mathrm{mg} / \mathrm{kg}$ ) to EAC-bearing mice, the level of lipid peroxidation reduced by $12.22 \%, 21.83 \%, 31.44 \%$, and $43.23 \%$, respectively, as compared to EAC control group $(P<$ $.05)$.

Figure 7 illustrates the effect of ZMS on reduced glutathione in EAC-bearing mice. Tumor induction by inoculation of EAC drastically decreased the GSH content by $70 \%(P<.001)$ in control group. The administration of ZMS at $100,200,400$ and $800 \mathrm{mg} / \mathrm{kg}$ to EAC bearing animals increased the GSH content by $21.97 \%, 30.39 \%, 37.71 \%$ and $41.32 \%$, respectively, as compared to untreated EAC control group $(P<.05)$.

3.8. Antioxidant Enzymes. ZMS significantly restored the antioxidant status of tumor-bearing mice. The effect of administration of ZMS to EAC bearing animals at 100, 


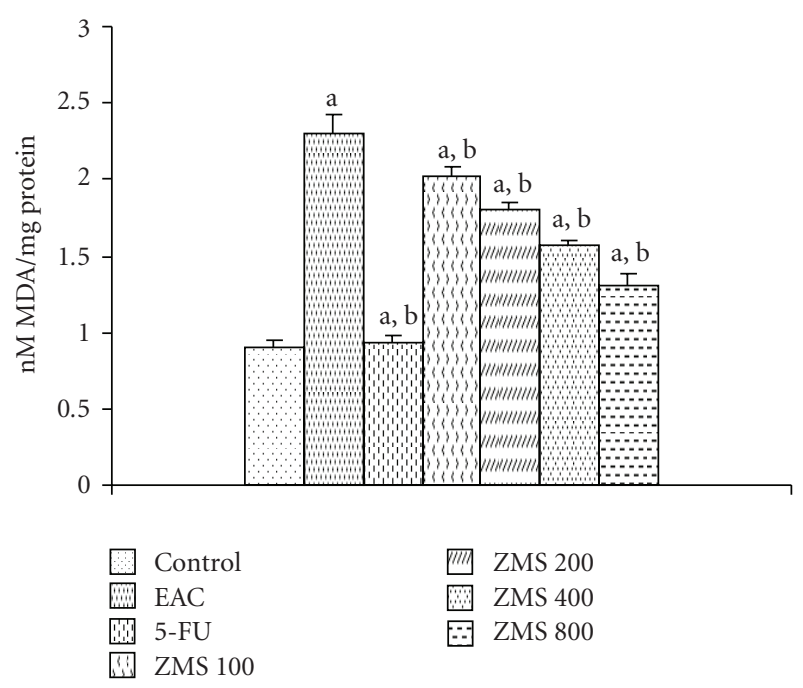

FIGURE 6: Reduction in lipid peroxidation in EAC-bearing mice after ZMS treatment. The results are presented as Mean \pm S.E.M. $(n=10)$. (a) $P<.001$ in comparison to normal control; (b) $P<.05$ in comparison to EAC control group.

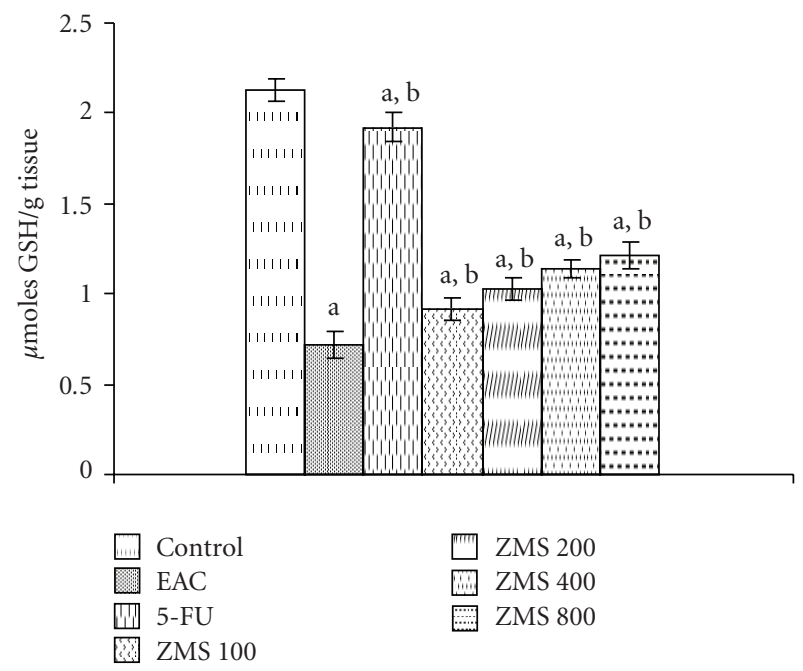

Figure 7: Augmentation of glutathione content in EAC bearing mice after ZMS treatment. The results are presented as Mean \pm S.E.M. $(n=10)$. (a) $P<.001$ in comparison to normal control; (b) $P<.05$ in comparison to EAC control group.

200,400 , and $800 \mathrm{mg} / \mathrm{kg}$ efficiently enhanced the superoxide dismutase activity by $11.01 \%, 24.62 \%, 31.52 \%$, and $47.12 \%$, respectively, as compared to EAC control group (Figure 8).

Catalase activity was evaluated in terms of $\mathrm{H}_{2} \mathrm{O}_{2}$ reduced $/ \mathrm{min} / \mathrm{mg}$ of protein. The catalase level in EAC bearing mice was found to decrease by $57.80 \%$ as compared to normal control group $(P<.001)$. However, treatment of EAC bearing mice with different doses of ZMS enhanced the catalase activity in a dose-dependent manner (Figure 9). At the highest dose of $800 \mathrm{mg} / \mathrm{kg}$, rise in catalase activity was found to be $44.31 \%$ as compared to EAC control group $(P<.05)$.

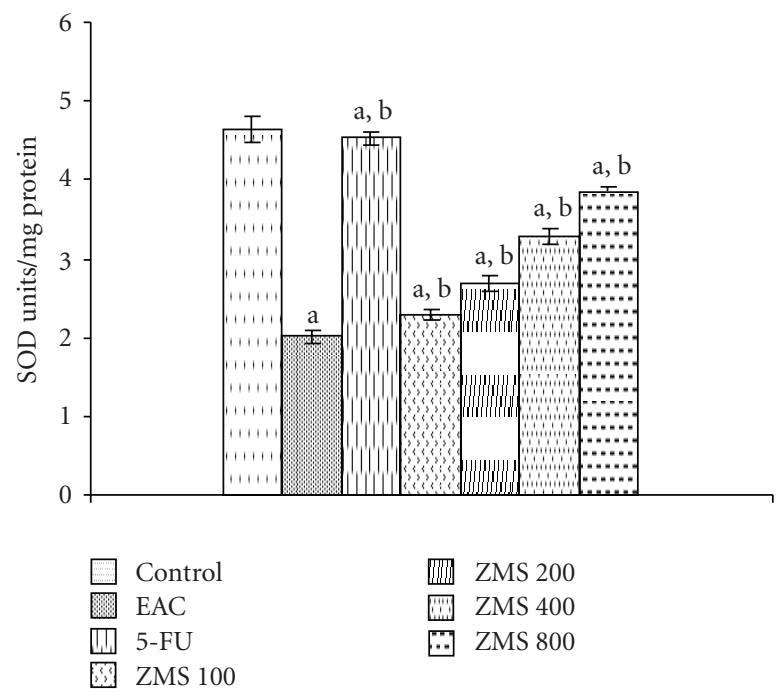

Figure 8: Augmentation of superoxide dismutase activity in EAC bearing mice after ZMS treatment. The results are expressed as Mean \pm S.E.M. $(n=10)$. (a) $P<.001$ in comparison to normal control; (b) $P<.05$ in comparison to EAC control group.

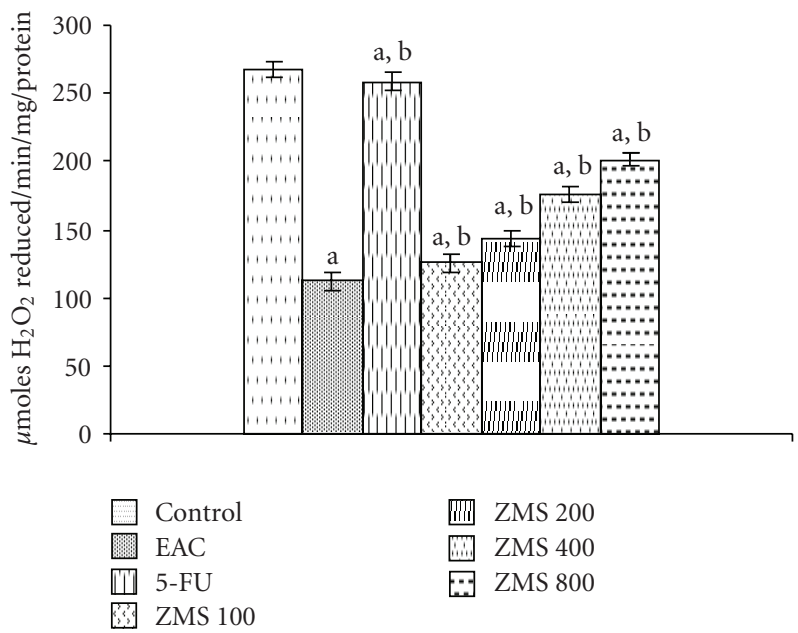

FIgURE 9: Augmentation of catalase activity in EAC bearing mice after ZMS treatment. The results are expressed as Mean \pm S.E.M. $(n=10)$. (a) $P<.001$ in comparison to normal control; (b) $P<.05$ in comparison to EAC control group.

\section{Discussion}

One of the goals of anticancer potential of any drug/extract is the induction of apoptosis in cancer cells [27]. Apoptosis or programmed cell death is one of the most important targets for cancer treatment comprising chemotherapy as well as chemoprevention. It is characterized by membrane blebbing, cytoplasmic condensation, formation of apoptotic bodies, DNA fragmentation, alteration in membrane symmetry, activation of cascade of caspases, and loss of mitochondrial membrane potential [28]. In the present study, cytotoxic potential of ZMS was assessed by MTT assay against cancer cell lines (HL-60, Molt-4, HeLa). Assay is based upon 


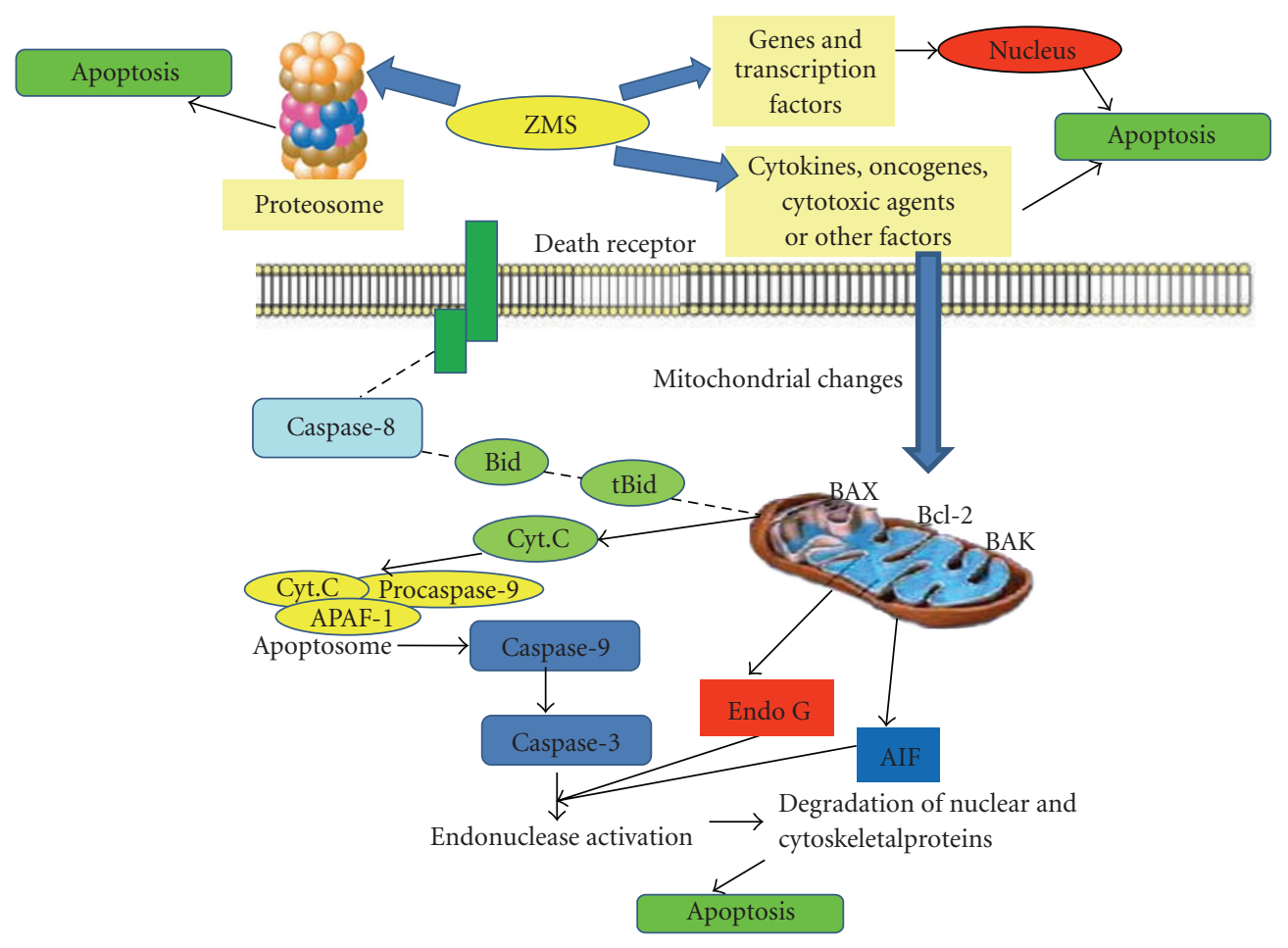

Figure 10: Presumptive mechanism of apoptosis induction by ZMS. ZMS may affect the genes and transcription factors or may affect proteosome to induce apoptosis or may trigger some signals that directly change the mitochondrial permeability transition pore. This induces changes in the members of Bcl-2 family. It may interact with BAX (Bcl-2 associated X protein) and BAK (Bcl-2-proapoptotic member) and stimulate the release of cyt. C (Cytochrome C). Cytochrome $\mathrm{C}$ released from mitochondria binds to APAF-1 (Apoptotic protease activating factor-1) and procaspase-9 forming apoptosome and activating caspase-9 which in turn activates executor caspases (Caspase 3, 6, and 7) leading to cell death via apoptosis.

reduction of yellow tetrazolium salt (MTT) by metabolically active cells to a dark blue formazan [29], which has been employed by many workers to measure cytotoxicity to cells $[30,31]$. ZMS showed significant cytotoxic effect against different cell lines with minimum IC50 value of $20 \mu \mathrm{g} / \mathrm{mL}$ against HL-60 cells and no significant cytotoxicity to normal cell line was observed. The criteron of cytotoxicity activity for crude extracts established by American National Cancer Institute is an IC50 value of $<30 \mu \mathrm{g} / \mathrm{mL}$ in preliminary assay [32], which was observed only against HL-60 cells and hence further investigations were carried out using HL-60 cell line. To investigate the mechanism of cell death induced by ZMS in HL-60 cells, flow cytometric analysis was done by PI and annexin V-FITC labelling to confirm apoptosis/necrosis as a marker to assess apoptosis [33]. During apoptosis, a number of changes occur in cell surface markers that show affinity for PI and annexin V-FITC labelling [34]. The results of the present study indicated an increase in apoptotic population induced by the extract in a concentration-dependent manner. Earlier Malik et al. [35] reported withaferin A as apoptosis inducer utilizing flow cytometric analysis. Another important characteristic of apoptosis induction is DNA fragmentation and measurement of DNA content makes it possible to identify apoptotic cells. To recognize the cell cycle phase specificity and to quantify apoptosis, propidium iodide
(PI) dye binds to DNA in cells at all stages of the cell cycle, and the intensity with which a cell nucleus emits fluorescent light is directly proportional to its DNA content. The increase in hypo diploid sub Go population in our results indicates the induction of apoptosis, as sub Go peak is reported to be a quantitative indicator of apoptosis [16]. Uvaretin, Isouvaretin, and Diuvaretin are known triterpenoid established as apoptosis inducer using the same parameters [36]. DNA fragmentation was confirmed by agarose gel electrophoresis. The nuclear DNA of apoptotic cells shows a characteristic laddering pattern of oligonucleosomal fragments, which is regarded as the hallmark of apoptosis [37].

Plant extract at various doses was tested in vivo against Ehrlich ascite carcinoma induced tumor in Swiss albino mice. Ascite fluid is the direct nutritional source for tumor cells and a rapid increase in ascite fluid with tumor growth would be a mean to meet the nutritional requirement of tumor cells [38]. Treatment with ZMS inhibited tumor volume and viable cell count and also increased the life span of tumor-bearing mice. Prolongation of life span of animal has been well documented as criteria for judging the drug activity [39]. Myelosuppression and anaemia are the major problems of cancer chemotherapy [40]. Treatment with ZMS reverted back the $\mathrm{Hb}$ content, $\mathrm{RBC}$, and WBC count towards normalcy showing its protective action on hematopoetic 
system. Our results are in corroboration with the findings of Gupta et al. [41] who reported a similar effect of Indigofera aspalathoides against Ehrlich ascites carcinoma.

Excessive production of free radicals results in oxidative stress which leads to damage of macromolecules like lipids and induces lipid peroxidation [42, 43]. Malondialdehyde (end product of lipid peroxidation) has been reported to increase in carcinomous tissues than nondiseased organs [44]. Glutathione, a potent inhibitor of neoplastic process is found particularly in liver and known to exhibit protective function against free radicals [42]. In the present study, ZMS treatment reduced lipid peroxidation and enhanced glutathione content in tumor-bearing animals. Superoxide dismutase and catalase are free radical scavenging enzymes present in all oxygen metabolizing cells and provide defence against potentially damaging entities of superoxide and hydrogen peroxide. Inhibition of both the enzymes as a result of tumor growth observed in the present study is in corroboration with earlier reports [45]. Administration of ZMS at different doses increased the SOD and CAT levels in a dose-dependent manner indicating the protective function of ZMS. In our previous study [14], phytochemical analysis of the extract showed the presence of betulinic acid which is a known anticancer agent [11] and the antitumor and apoptosis inducing property of extract may be in part due to the presence of betulinic acid. It is well established that betulinic acid activates apoptosis independent of the death receptors (CD95/Fas), but induces the successive activation of caspase 9 and caspase 3 [46, 47]. The phytochemical analysis of the extract in our previous study has also revealed the presence of alkaloids and flavonoids, which could also be expected to be responsible for its bioactivity. Although at this stage the exact mechanism underlying apoptosis induction by extract is difficult to predict, yet it could be due to activation of mitochondrial pathway or its effect on proteosome or other gene and transcription factors. The hypothetical mechanism is outlined in Figure 10.

In conclusion, the present study highlights the antitumor and cytotoxic potential of seed extract of Ziziphus mauritiana. Further studies to characterize the active principles and elucidate the mechanism of action are in progress.

\section{Acknowledgment}

The financial aid to the department in the form of FIST grant for the purchase of instruments by DST, Government of India is fully acknowledged.

\section{References}

[1] G. F. Gonzales and L. G. Valerio Jr., "Medicinal plants from Peru: a review of plants as potential agents against cancer," Anti-Cancer Agents in Medicinal Chemistry, vol. 6, no. 5, pp. 429-444, 2006.

[2] J. J. Rafter, "Scientific basis of biomarkers and benefits of functional foods for reduction of disease risk: cancer," British Journal of Nutrition, vol. 88, no. 2, pp. S219-S224, 2002.

[3] S. Madhusudan and M. R. Middleton, "The emerging role of DNA repair proteins as predictive, prognostic and therapeutic targets in cancer," Cancer Treatment Reviews, vol. 31, no. 8, pp. 603-617, 2005.

[4] M. D. Mignogna, S. Fedele, and L. Lo Russo, "The World cancer report and the burden of oral cancer," European Journal of Cancer Prevention, vol. 13, no. 2, pp. 139-142, 2004.

[5] J. Morton, "Indian jujube," in Fruits of Warm Climates, J. F. Mortan and F. L. Miami, Eds., pp. 272-275, Center for New Crops \& Plant Products, Purdue University, Lafayette, Ind, USA, 1987, http://www.hort.purdue.edu/newcrop/morton/indian_jujube.html.

[6] E. W. M. Verheij and M. Calabura, "Plant resources of SouthEast Asia 2," in Edible Fruits and Nuts, E. W. M. Verheij and R. E. Coronel, Eds., pp. 223-225, PROSEA, Pudoc, Wageningen, The Netherlands, 1991.

[7] A. R. Ndhala, C. H. Mupure, K. Chitindingue, M. A. N. Benhura, and M. Muchuweti, "Antioxidant potentials and degree of polymerization of six wild fruits," Life Science Research Assays, vol. 1, pp. 87-92, 2006.

[8] D. Dahiru, E. T. William, and M. S. Nadro, "Protective effect of Ziziphus mauritiana leaf extract on carbon tetrachlorideinduced liver injury," African Journal of Biotechnology, vol. 4, no. 10, pp. 1177-1179, 2005.

[9] D. Dahiru and O. Obidoa, "Pretreatment of albino rats with aqueous leaf extract of Zizyphus mauritiana protects against alcohol induced liver damage," Tropical Journal of Pharmaceutical Research, vol. 6, pp. 705-710, 2007.

[10] A. Bhatia and T. Mishra, "Free radical scavenging and antioxidant potential of Ziziphus mauritiana (Lamk.) seed extract," Journal of Complementary and Integrative Medicine, vol. 8, pp. 42-46, 2009.

[11] E. Pisha, H. Chai, I.-S. Lee et al., "Discovery of betulinic acid as a selective inhibitor of human melanoma that functions by induction of apoptosis," Nature Medicine, vol. 1, no. 10, pp. 1046-1051, 1995.

[12] S. Ramadoss, M. Jaggi, and M. J. A. Siddiqui, "Use of betulinic acid and its derivatives for inhibiting cancer growth and a method of monitoring this," Assignee: Dabur Research Foundation. US patent No.6048847, 2000.

[13] F. Vahedi, M. Fathi Najafi, and K. Bozari, "Evaluation of inhibitory effect and apoptosis induction of Zyzyphus Jujube on tumor cell lines, an in vitro preliminary study," Cytotechnology, vol. 56, no. 2, pp. 105-111, 2008.

[14] T. Mishra and A. Bhatia, "Augmentation of expression of immunocytes' functions by seed extract of Ziziphus mauritiana (Lamk.)," Journal of Ethnopharmacology, vol. 127, no. 2, pp. 341-345, 2010.

[15] B. Shashi, S. Jaswant, R. J. Madhusudana, S. A. Kumar, and Q. G. Nabi, "A novel lignan composition from Cedrus deodara induces apoptosis and early nitric oxide generation in human leukemia Molt-4 and HL-60 cells," Nitric Oxide, vol. 14, no. 1, pp. 72-88, 2006.

[16] G. Del Bino, Z. Darzynkiewicz, C. Degraef, R. Mosselmans, D. Fokan, and P. Galand, "Comparison of methods based on annexin-V binding, DNA content or TUNEL for evaluating cell death in HL-60 and adherent MCF-7 cells," Cell Proliferation, vol. 32, no. 1, pp. 25-37, 1999.

[17] A. Müller, J. Hacker, and B. C. Brand, "Evidence for apoptosis of human macrophage-like HL-60 cells by Legionella pneumophila infection," Infection and Immunity, vol. 64, no. 12, pp. 4900-4906, 1996.

[18] A. Bhatia and T. Mishra, "Hypoglycemic activity of Ziziphus mauritiana aqueous ethanol seed extract in alloxan-induced diabetic mice," Pharmaceutical Biology, vol. 48, no. 6, pp. 604$610,2010$. 
[19] M. Gupta, U. K. Mazumder, N. Rath, and D. K. Mukhopadhyay, "Antitumor activity of methanolic extract of Cassia fistula L. seed against Ehrlich ascites carcinoma," Journal of Ethnopharmacology, vol. 72, no. 1-2, pp. 151-156, 2000.

[20] F. E. D'Armour, F. R. Blood, and D. A. Belden, The Manual for Laboratory Work in Mammalian Physiology, The University of Chicago Press, Chicago, Ill, USA, 3rd edition, 1965.

[21] A. Bhatia and J. Kaur, "Evaluation of hematological and immunological parameters in mice exposed to sublethal and subchronic doses of dimethoate," Toxic Substance Mechanisms, vol. 19, no. 2, pp. 99-109, 2000.

[22] H. Ohkawa, N. Ohishi, and K. Yagi, "Assay for lipid peroxides in animal tissues by thiobarbituric acid reaction," Analytical Biochemistry, vol. 95, no. 2, pp. 351-358, 1979.

[23] G. L. Ellman, "Tissue sulfhydryl groups," Archives of Biochemistry and Biophysics, vol. 82, no. 1, pp. 70-77, 1959.

[24] S. Marklund and G. Marklund, "Involvement of the superoxide anion radical in the autoxidation of pyrogallol and a convenient assay for superoxide dismutase," European Journal of Biochemistry, vol. 47, no. 3, pp. 469-474, 1974.

[25] H. E. Aebi, "Catalase," in Methods in Enzymatic Analysis, H. O. Bergmeyer, Ed., vol. 3, pp. 273-386, Academic Press, New York, NY, USA, 1983.

[26] O. H. Lowry, N. J. Rosenbrough, A. L. Farr, and R. J. Randall, "Protein measurement with the Folin phenol reagent," The Journal of Biological Chemistry, vol. 193, no. 1, pp. 265-275, 1951.

[27] C. Denicourt and S. F. Dowdy, "Medicine targeting apoptotic pathways in cancer cells," Science, vol. 305, no. 5689, pp. 1411$1413,2004$.

[28] K. Kang, H. J. Lee, C. Y. Kim et al., "The chemopreventive effects of Saussurea salicifolia through induction of apoptosis and phase II detoxification enzyme," Biological and Pharmaceutical Bulletin, vol. 30, no. 12, pp. 2352-2359, 2007.

[29] T. Mosmann, "Rapid colorimetric assay for cellular growth and survival: application to proliferation and cytotoxicity assays," Journal of Immunological Methods, vol. 65, no. 1-2, pp. 55-63, 1983.

[30] S. J. Uddin, I. Darren Grice, and E. Tiralongo, "Cytotoxic effects of Bangladeshi medicinal plant extracts," Evidencebased Complementary and Alternative Medicine. In press.

[31] B. Saad, S. Dakwar, O. Said et al., "Evaluation of medicinal plant hepatotoxicity in co-cultures of hepatocytes and monocytes," Evidence-based Complementary and Alternative Medicine, vol. 3, no. 1, pp. 93-98, 2006.

[32] M. Suffness and J. M. Pezzuto, "Assays related to cancer drug discovery," in Methods in Plant Biochemistry: Assays for Bioactivity, K. Hostettmann, Ed., vol. 6, pp. 71-133, Academic Press, London, UK, 1990.

[33] M. Kawamura and H. Kasai, "Delayed cell cycle progression and apoptosis induced by hemicellulase-treated Agaricus blazei," Evidence-Based Complementary and Alternative Medicine, vol. 4, no. 1, pp. 83-94, 2007.

[34] I. Vermes, C. Haanen, H. Steffens-Nakken, and C. Reutelingsperger, "A novel assay for apoptosis. Flow cytometric detection of phosphatidylserine expression on early apoptotic cells using fluorescein labelled Annexin V," Journal of Immunological Methods, vol. 184, no. 1, pp. 39-51, 1995.

[35] F. Malik, A. Kumar, S. Bhushan et al., "Reactive oxygen species generation and mitochondrial dysfunction in the apoptotic cell death of human myeloid leukemia HL-60 cells by a dietary compound withaferin A with concomitant protection by Nacetyl cysteine," Apoptosis, vol. 12, no. 11, pp. 2115-2133, 2007.
[36] N. Nakatani, M. Ichimaru, M. Moriyasu, and A. Kato, "Induction of apoptosis in human promyelocytic leukemia cell line HL-60 by C-benzylated dihydrochalcones, uvaretin, isouvaretin and diuvaretin," Biological and Pharmaceutical Bulletin, vol. 28, no. 1, pp. 83-86, 2005.

[37] H. M. Lien, H. W. Lin, Y. J. Wang et al., "Inhibition of anchorage-independent proliferation and G0/G1 cellcycle regulation in human colorectal carcinoma cells by 4,7-Dimethoxy-5-methyl-1,3-benzodioxole isolated from the fruiting body of Antrodia camphorate," Evidence-based Complementary and Alternative Medicine. In press.

[38] Y. Rajeshwar, M. Gupta, and U. K. Mazumder, "Antitumor activity and in vivo antioxidant status of Mucuna pruriens (Fabaceae) seeds against Ehrlich ascites carcinoma in Swiss albino mice," Iranian Journal of Pharmacology \& Therapeutics, vol. 4, pp. 46-53, 2005.

[39] H. C. Hoagland, "Hematologic complications of cancer chemotherapy," Seminars in Oncology, vol. 9, no. 1, pp. 95$102,1982$.

[40] V. E. Price and R. E. Greenfield, "Anaemia in cancer," in Advances in Cancer Research, J. P. Greenstein and A. Haddow, Eds., vol. 5, pp. 199-200, Academic Press, New York, NY, USA, 1958.

[41] M. Gupta, U. K. Mazumdar, P. K. Haldar, C. C. Kandar, L. Manikandan, and G. P. Senthil, "Anticancer activity of Indigofera aspalathoides and Wedelia calendulaceae in Swiss albino mice," Iranian Journal of Pharmaceutical Research, vol. 6, pp. 141-145, 2007.

[42] A. J. Sinclair, A. H. Barnett, and J. Lunie, "Free radical and anti-oxidant systems in human health and diseases," British Journal of Hospital Medicine, vol. 43, pp. 334-344, 1990.

[43] K. Yagi, "Lipid peroxides and human diseases," Chemistry and Physics of Lipids, vol. 45, pp. 337-351, 1991.

[44] Y. Sun, L. W. Oberley, J. H. Elwell, and E. Sierra-Rivera, "Antioxidant enzyme activities in normal and transformed mouse liver cells," International Journal of Cancer, vol. 44, no. 6, pp. 1028-1033, 1989.

[45] S. L. Marklund, N. G. Westman, E. Lundgren, and G. Roos, "Copper- and zinc-containing superoxide dismutase, manganese-containing superoxide dismutase, catalase, and glutathione peroxidase in normal and neoplastic human cell lines and normal human tissues," Cancer Research, vol. 42, no. 5, pp. 1955-1961, 1982.

[46] A. G. Pokrovskii, A. B. Shintyapina, N. V. Pronkina et al., "Activation of apoptosis by derivatives of betulinic acid in human tumor cells in vitro," Doklady Biochemistry and Biophysics, vol. 407, no. 1, pp. 94-97, 2006.

[47] S. Fulda and K.-M. Debatin, "Betulinic acid induces apoptosis through a direct effect on mitochondria in neuroectodermal tumors," Medical and Pediatric Oncology, vol. 35, no. 6, pp. 616-618, 2000. 


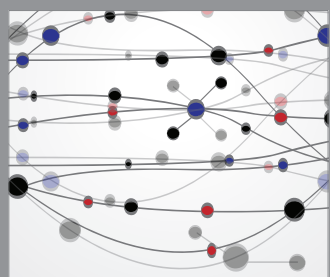

The Scientific World Journal
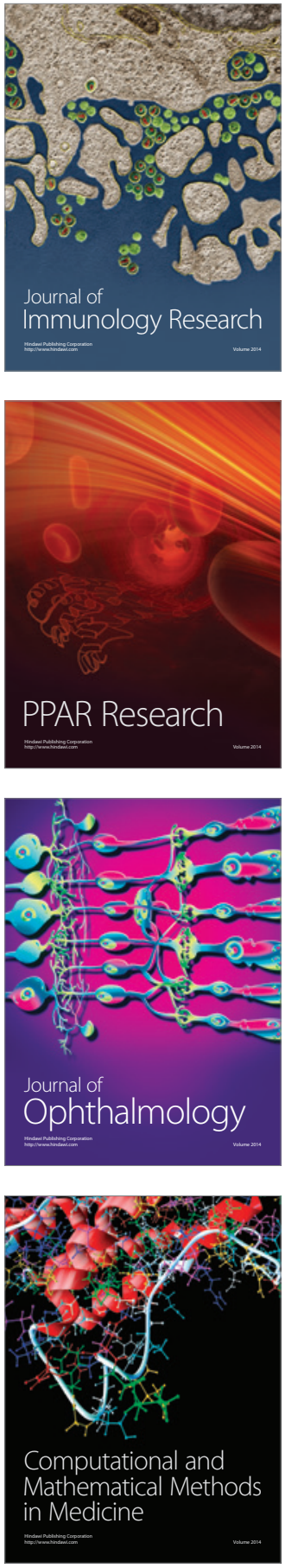

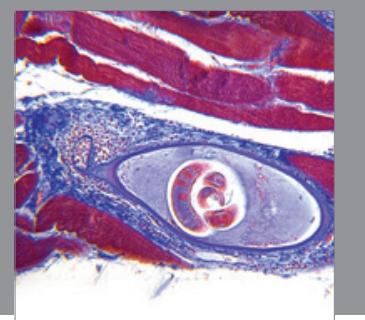

Gastroenterology

Research and Practice
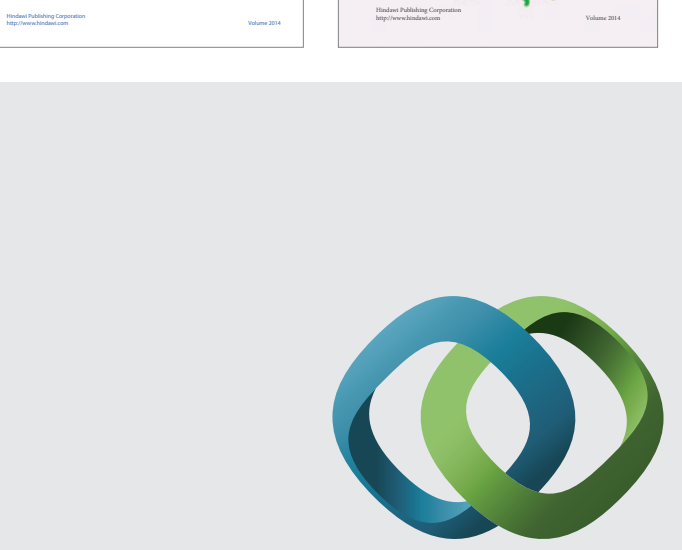

\section{Hindawi}

Submit your manuscripts at

http://www.hindawi.com
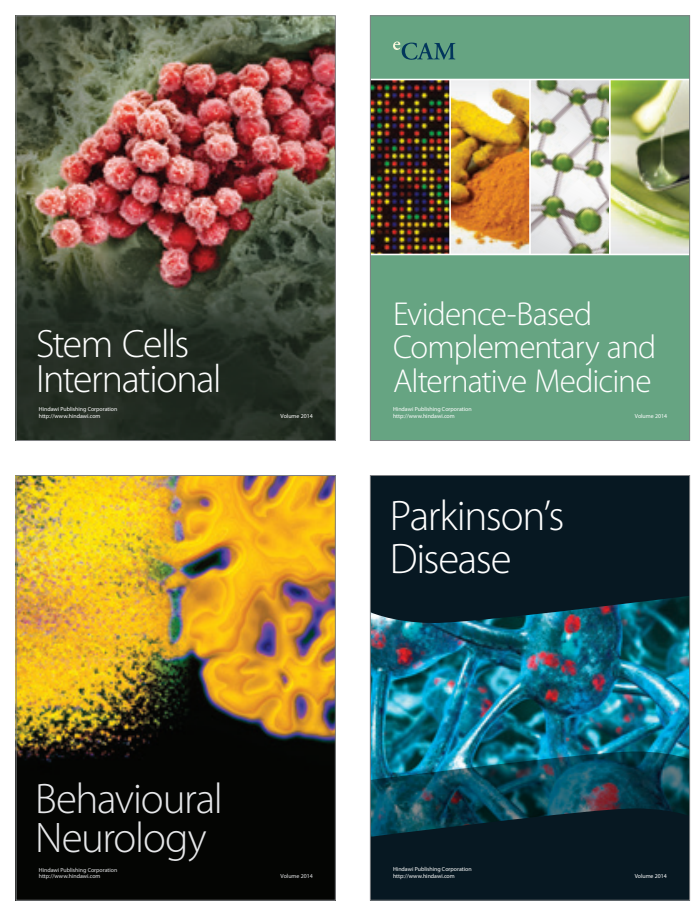

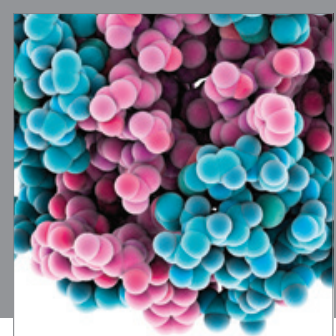

Journal of
Diabetes Research

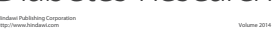

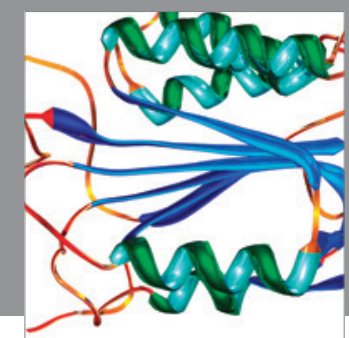

Disease Markers
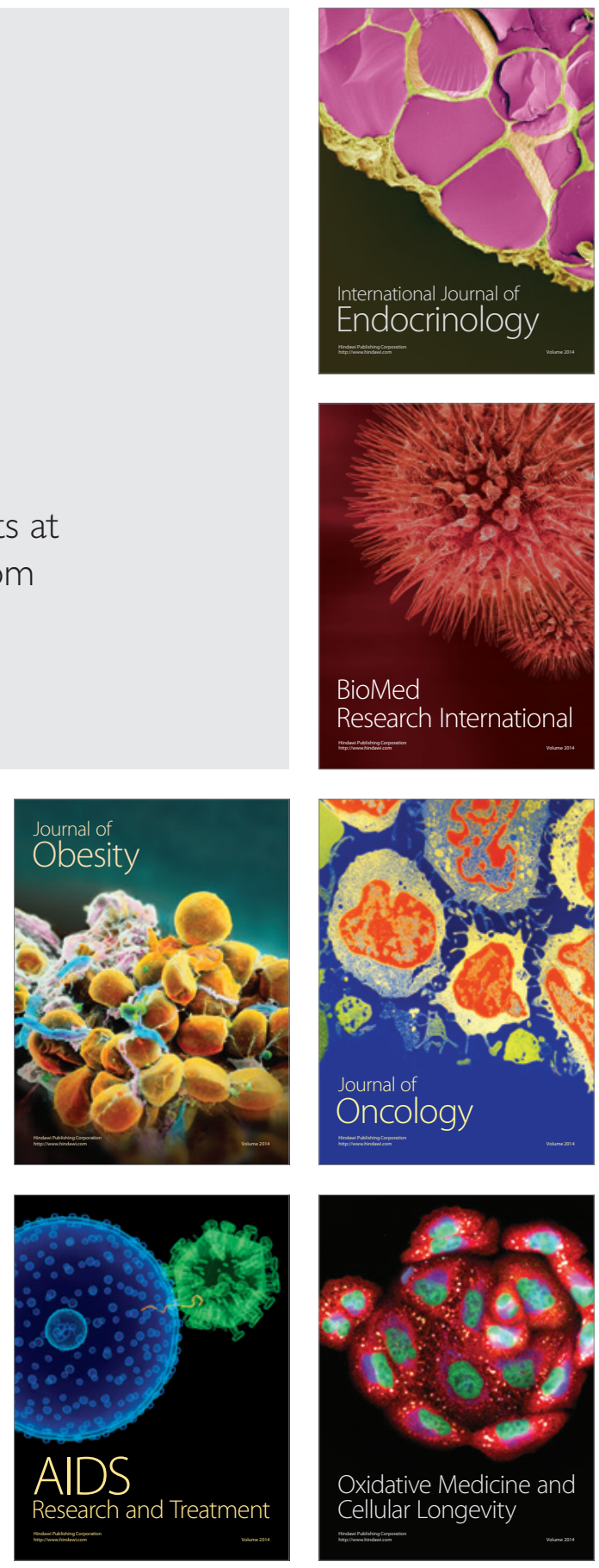